\title{
Aggregate Fish Biomass and Yield on Georges Bank, 1960-87
}

\author{
R. K. Mayo, M. J. Fogarty, and F. M. Serchuk \\ National Oceanic and Atmospheric Administration \\ National Marine Fisheries Service, Northeast Fisheries Science Center \\ Woods Hole, Massachusetts 02543 USA
}

\begin{abstract}
The Georges Bank ecosystem has undergone dramatic changes in biomass and species dominance under exploitation. Sharp declines in the biomass of both pelagic and demersal fish populations have occurred associated with rapid increases in fishing effort by distant water fleets. We corrected nominal effort series for changes in vessel size, gear type and country of origin in an attempt to provide a measure of the intensity of the perturbation resulting from large scale changes in exploitation patterns on Georges Bank. A fourfold increase was noted in standardized effort over the period 1960-72. Declines in catch-perstandard day fished, and relative biomass indices derived from research vessel surveys indicated marked decreases in all components of the system during the period 1960-76. Decreases in fishing effort were effected with the implementation of extended jurisdiction to 200 miles in 1977; however, several major stocks had collapsed by that time.

Fundamental changes were noted in the production levels on Georges Bank during the period 1960-76. Declines in overall production can be attributed largely to the collapse of the herring population by 1976-77 under heavy exploitation. Recent increases in biomass of elasmobranchs and principal pelagic species (herring and mackerel) have resulted in further shifts in system structure. The biomass of piscivores is currently high and this shift may act synergistically with increasing exploitation rates to cause further declines in biomass of commercially desirable species.
\end{abstract}

\section{Introduction}

Georges Bank is a highly productive marine ecosystem with an extensive history of exploitation. Structural features of this system, including patterns of energy flow and utilization, changes in biomass, production and species composition and effects of exploitation, have been extensively studied (see reviews by Cohen and Grosslein, 1987; Sissenwine, 1987; Fogarty et al., 1987). Sharply increased levels of exploitation associated with the advent and expansion of distant water fisheries on Georges Bank in the early-1960s resulted in major perturbations to the system (Clark and Brown, 1977; 1979). Between 1961 and 1973, total finfish and squid landings from Georges Bank nearly quadrupled, while fishing effort increased sixfold. Virtually all of the principal demersal and pelagic resources within the region became intensively exploited and overfished. As a consequence, marked reductions in abundance (50-90\%) occurred for several important species and total finfish biomass declined by over 50\% (Brown et al., 1976).

Changes in ecosystem structure in response to exploitation have been observed in several large regions including the North Sea (Hempel, 1978) and the Great Lakes (Holling, 1973; Christie and Spangler, 1987). However, the general resilience of ecosystems to sustained perturbations (e.g. exploitation) is still not known. It is often implicitly assumed that these systems will revert to their original configuration following a reduction in exploitation rates. However, selective harvesting practices can alter species composition and affect predator-prey and competitive interactions among different components of the system. Beddington (1984) noted that changes in system structure induced by harvesting may not be reversible and that exploited ecosystems may exhibit multiple stable states.

In this paper, we describe trends in aggregate fish biomass and yield on Georges Bank, and explore the consequences of large scale changes in exploitation levels on the fish populations. The analyses are based on commercial catch and effort data for NAFO Div. $5 Z$ (Fig. 1) for the period 196087 , and research vessel survey information during 1963-88. We update the analyses of Brown et al. (1976) and Clark and Brown (1977; 1979) and evaluate the effects of harvesting on the structure of the Georges Bank ecosystem.

\section{History of exploitation and regulation of Georges Bank fisheries}

Offshore groundfish fisheries developed on Georges Bank between 1720 and 1750, primarily for 


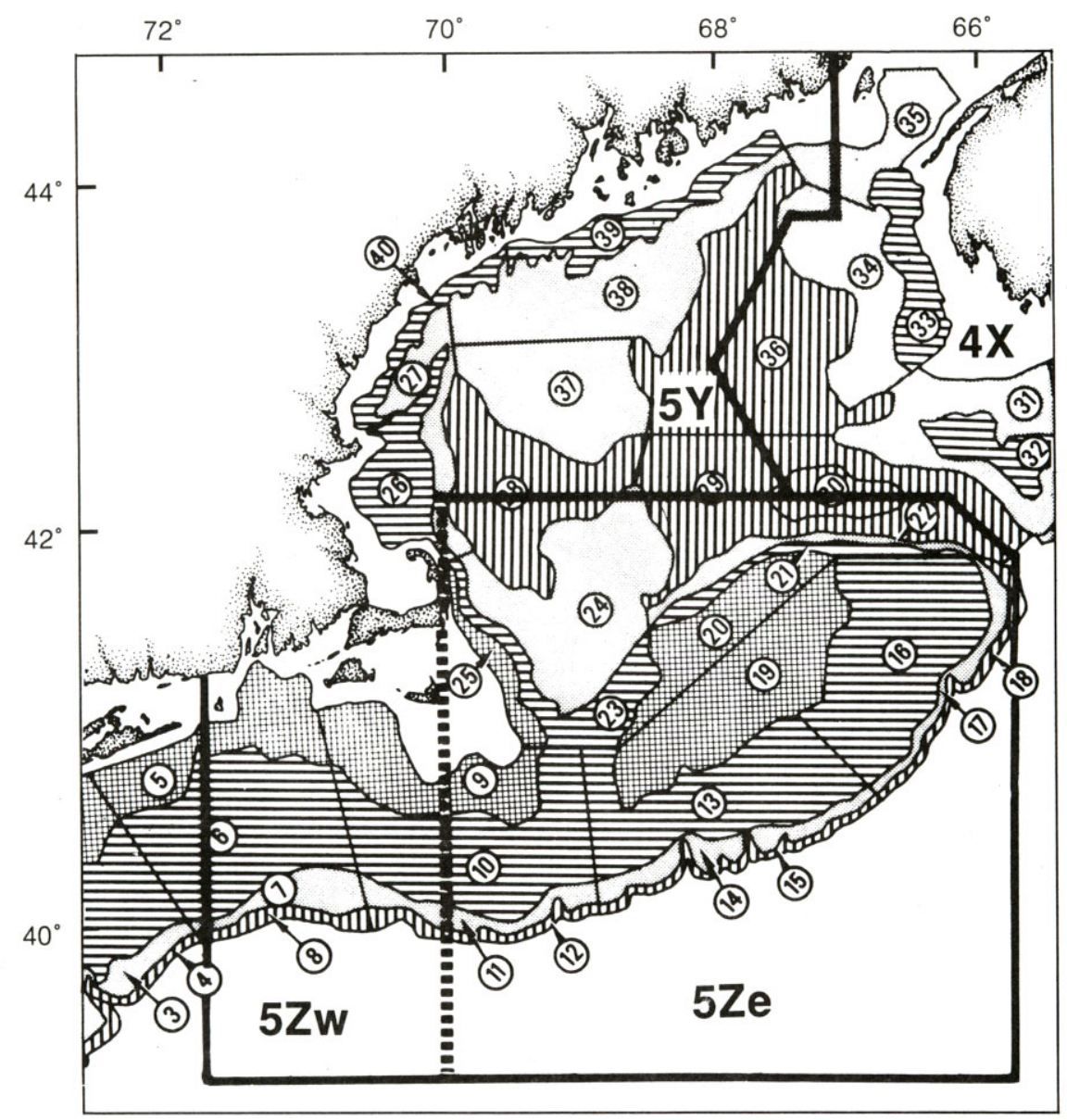

Fig. 1. The Georges Bank region off the northeastern coast of the United States. NAFO areas (Div. 4X, 5Y and Subdiv. 5Ze and 5Zw) and NEFC bottom trawl survey sampling strata (numbered shaded areas) are indicated.

Atlantic cod (Gadus morhua), but expanded during the early-1800s to include Atlantic halibut (Hippoglossus hippoglossus) and Atlantic mackerel (Scomber scombrus) (German, 1987). Technological improvements (e.g. purse seines, line trawls, otter trawls) and increased market demand for iced, fresh fish stimulated rapid growth and diversification of the Georges Bank fishery (Bourne, 1987). Landings of Georges Bank haddock (Melanogrammus aeglefinus) increased during the late-1870s and early-1880s, as did catches of hake (Merluccius bilinearis and Urophycis spp.), cusk (Brosme brosme) and pollock (Pollachius virens).

In the early part of the twentieth century, steam and diesel-powered vessels and freezing and refrigeration technology transformed the character of the offshore fisheries. Coupled with increased use of otter trawls and power-driven fishing equipment, these developments significantly enhanced the mobility, profitability and collective fishing power of the Georges Bank fishing fleets. By the early-1920s, haddock had become the mainstay of the demersal fishery, accounting for about two-thirds of the USA groundfish catch from the Bank (Lange and Palmer, 1985). Flounder catches also increased during the 1920s due to the introduction of filleting techniques and awareness that significant winter flounder (Pleuronectes americanus) and yellowtail flounder (Pleuronectes ferrugineus) stocks existed on the southern flank of the Bank.

Between 1930 and 1960, the Georges Bank fishery was relatively stable, except for the intervention of World War II (Hennemuth and Rockwell, 1987). In general, fishery growth did not exceed resource capacities, although attention was raised over the large quantities of small haddock discarded in the Georges Bank fishery (Herrington, 1935; Graham and Premetz, 1955). As a result of these concerns (and a sharp drop in haddock catches), intensive research and port sampling programs were established by the U.S. Bureau of Fisheries in the 1930s to investigate changes in haddock 
landings and abundance (Schuck, 1951). These programs were expanded in the 1940s and 1950s to encompass other species, and a comprehensive North Atlantic fishery statistics collection system was implemented in 1944 (Rounsefell, 1948). Both initiatives were refined in later years but proved invaluable in providing the foundation for research and management activities under the International Commission for the Northwest Atlantic Fisheries (ICNAF) established in 1949, and the USA Magnuson Fishery Conservation and Management Act (MFCMA) enacted in 1976.

Prior to 1960, Georges Bank was fished almost exclusively by the USA. During the 1960s and early1970s, however, the nature of the fishery changed dramatically with the arrival of distant water fleets from the Union of Soviet Socialist Republics (USSR), Poland, German Democratic Republic (GDR), Federal Republic of Germany (FRG), Japan and other countries. Although these fleets initially exploited Atlantic herring (Clupea harengus), effort was soon directed towards abundant stocks of groundfish and flounders. Total yield from Georges Bank increased sharply from 240000 tons in 1960 to about 780000 tons in 1965 (Fig. 2) due to substantial increases in the groundfish component (principally haddock and silver hake). Subsequently, groundfish landings sharply declined and fishing effort was redirected to pelagic species (principally herring, and later, mackerel) and squid (I/lex illecebrosus and Loligo pealei). The collapse of the herring and mackerel stocks during the mid-1970s, coupled with restricted effort imposed on distant water fleets after USA implementation of extended jurisdiction in 1976, resulted in a sharp decline in total yield from over 920000 tons in 1973 to 300 000-330 000 tons during 1977-1981. After 1981, declining groundfish stocks contributed to further reductions in total yield to less than 220000 tons in 1985 and 1986.

The significant decline in Northwest Atlantic fishery resources that accompanied the rapid expansion and extremely high fishing effort of the 1960s and 1970s was a major impetus for extending USA fisheries jurisdiction to 200 nautical miles in 1977 (i.e. the MFCMA). Since 1978, however, abundance of groundfish and flounders on Georges Bank has continued to decline to record-low levels (Northeast Fisheries Center, MS 1987), while pelagic stocks (primarily mackerel and herring) and non-target species (skates and spiny dogfish) have increased (U.S. Department of Commerce, 1988).

Prior to the first meeting of ICNAF in 1951, no legal basis existed for the management of offshore fishery resources in the Northwest Atlantic (Clark et al., 1982). Under ICNAF, minimum cod-end mesh

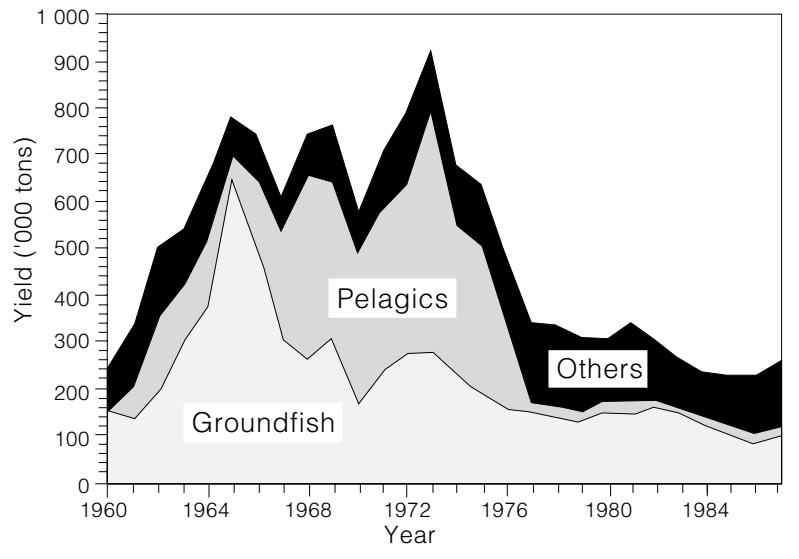

Fig. 2. Total nominal catches from Georges Bank (NAFO Div. 5Z) fisheries, 1960-87. Aggregate yields are presented by fishery components: groundfish, pelagic and 'other'.

size regulations ( $114 \mathrm{~mm}$ ) were implemented for the haddock fishery in 1953, expanded to the Georges Bank cod fishery in 1955, and eventually applied to most other Northwest Atlantic trawl fisheries (Hennemuth and Rockwell, 1987). In 1974, the minimum mesh size was increased to $130 \mathrm{~mm}$. Total allowable catch (TAC) limits were introduced by ICNAF in 1970 for haddock, followed by TACs on yellowtail flounder in 1971, and Georges Bank herring in 1972 (Grosslein et al., 1979). Beginning in 1972, TACs were subdivided into national allocations and, by 1974, TACs for 54 species-stocks had been established with 14 of these on Georges Bank. A limitation on total fishing effort from the Gulf of Maine to the Middle Atlantic region was proposed to ICNAF in 1973 to reduce fishing mortality to allow stocks to rebuild, but was not accepted. Rather a "two tier" catch quota system was developed and implemented in 1974 wherein the TAC (all species) for each country (i.e. the "second tier") was less than the sum of its directed-fisheries TACs (i.e. the "first tier"). Essentially, this was a first attempt to address multispecies management by recognizing that the total fishing mortality tolerable within the ecosystem was less than the sum of the directed fisheries mortalities over all species (Hennemuth, 1979). Fishing mortality on one stock would, because of by-catch, generate fishing mortality on other stocks. By having the "second tier" catch lower than the "first tier", national fleets were stimulated to direct their fishing effort to those resources of most value and in which by-catches would be relatively low so that "second tier" quotas would not be exceeded (Anthony, 1988). Implicitly, the "two tier" system accounted for biological interactions and the need to restore biomass levels on an ecosystem-wide basis. 
The USA withdrew from ICNAF at the end of 1976 and Canada terminated its membership at the end of 1977 . Both countries independently established management programs for resources within their extended (and at the time, overlapping) fisheries management zones. Since 1977, USA Georges Bank fisheries have been managed under Fishery Management Plans (FMPs) developed by the New England Fishery Management Council, one of eight regional management authorities created in 1976 by the MFCMA. To date, three different FMPs have regulated USA fisheries for demersal species on Georges Bank: the Atlantic Groundfish FMP (which regulated cod, haddock, and yellowtail flounder fisheries from March 1977 to March 1982); the Interim FMP for Atlantic Groundfish (which regulated the same three fisheries from April 1982 to September 1986), and the FMP for the Northeast Multispecies Fishery (which, since September 1986 , has regulated USA fisheries harvesting cod, haddock, yellowtail flounder, winter flounder, American plaice, [Hippoglossoides platessoides], redfish, [Sebastes spp.], witch flounder, [Glyptocephalus cynoglossus], and pollock). Management measures implemented under each of these FMPs have varied but have included: annual and quarterly catch quotas; weekly and/or trip landings restrictions (by vessel size and gear type); minimum mesh sizes; closed seasons and areas; by-catch limits; fishery closures; minimum landing sizes; small mesh/large mesh fishing areas and seasons; and record-keeping/reporting requirements (Serchuk and Wigley, 1992). The current FMP (New England Fishery Management Council, 1985) utilizes indirect controls on fishing mortality (i.e. minimum landings sizes, minimum mesh sizes, small mesh/large mesh fishing areas, and area closures) to:

"control fishing mortality on juveniles (primarily) and on adults (secondarily) of selected finfish stocks in order to maintain sufficient spawning potential so that year-classes replace themselves on a long-term average basis; and to similarly reduce fishing mortality for the purpose of rebuilding those stocks where it has been demonstrated that the spawning potential of the stock is insufficient to maintain a viable fishery resource; and further to promote the collection of data and information on the nature, behaviour and activity of the multi-species fishery, and on the management program."

Operationally, no formal distinction is made in the FMP among the various stocks of individual species within the management region (Eastern Maine through southern New England). In addition to the Northeast Multispecies FMP, three other USA federal management plans are presently in effect for other Georges Bank fisheries (FMP for American lobster; FMP for the Atlantic sea scallop fishery; and the Preliminary Management Plan (PMP) for the hake fisheries of the northwestern Atlantic (which only controls foreign fishing activities)).

Since 1978, Canadian fisheries on Georges Bank have been regulated under a management system based on single-species annual catch quotas. Additional measures have also been implemented including; minimum mesh sizes, spawning closure areas for haddock, limited entry, catch allocations by gear and tonnage class, and catch reporting requirements. In October 1984, the International Court of Justice delimited a maritime boundary between the USA and Canada in the Gulf of MaineGeorges Bank area. This decision effectively partitioned the management and utilization of many of the Georges Bank fishery resources (often across generally accepted stock boundaries) between the two nations. As a consequence, fishing activity by each country has subsequently been restricted to its own portion of Georges Bank, and management of transboundary stocks on the Bank is performed separately and independently by each country (Serchuk and Wigley, 1992).

\section{Materials and Methods}

\section{Data sources}

Catch and effort data from 1960 through 1987 were obtained from ICNAF Statistical Bulletins (ICNAF, 1962-1972) and from data files provided by the NAFO Secretariat. To maintain consistency through time, catches for all years were aggregated by species groups corresponding to those presented in the 1960 ICNAF Statistical Bulletin. Species categories (Table 1) were thus defined as: cod, haddock, redfish, silver hake, other groundfish, flounders, herring, other pelagics, other fish, and all species combined. A database which included only records assigned to Div. $5 Z$ (or Subdiv. 5Ze and $5 Z$ w) was constructed for each year excluding 1962 and 1981 because of apparent discrepancies in tonnage class codes (1962) and reported effort (1981). All records relating to fisheries targeting large pelagic fishes (swordfish, tunas, and sharks), lobsters, and bivalves were eliminated using combinations of main species and gear designations (Tables 1 and 2).

Standardized fishing effort was derived for all groundfish and small pelagic components of the Georges Bank fisheries and for a subset which only included effort associated with demersal fishing. The secondary subset was defined by first eliminating all records for midwater trawls and purse seines and those listing menhaden as the main species (Tables 1 and 2). We then examined the impact of several qualification levels ranging from 30 to $70 \%$ 
TABLE 1. Species groupings used in analyses of commercial fishing effort.

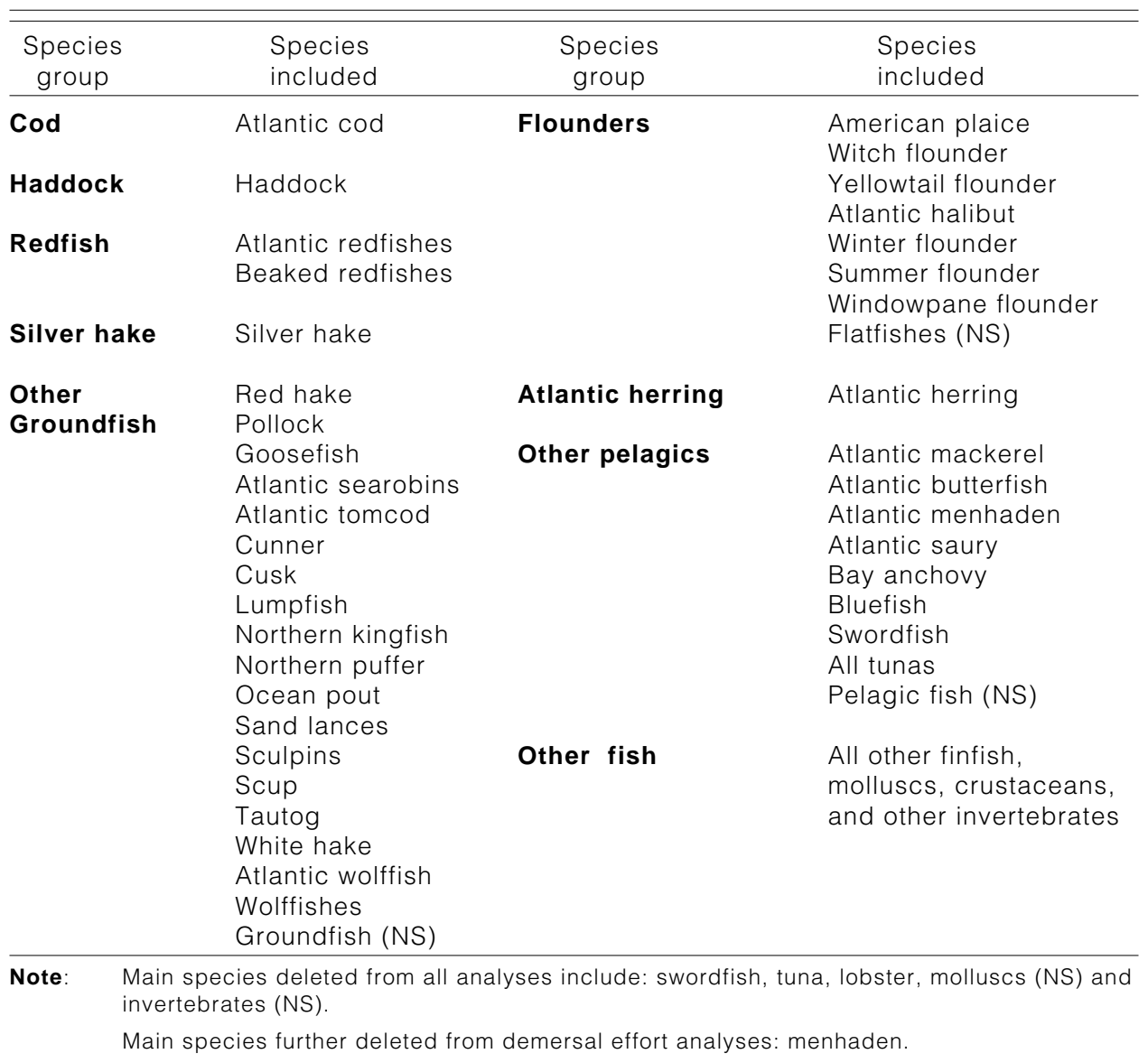

on changes in effort relative to catch. As the qualification level increases, elimination of "non-directed" effort can only be achieved by greatly reducing catches of non-pelagic species due to non-linearity in the catch/effort vs. qualification level relationship. Therefore, only those records in the secondary subset in which the catch of non-pelagic species represented $50 \%$ or more of the total catch were included for analysis of demersal catch and effort. Both data sets were then aggregated over months.

Factors incorporated in the effort standardization analyses were gear, tonnage class and country. To reduce the number of levels of each factor and to provide a more balanced statistical design, several gear types, countries and tonnage classes appearing infrequently in the data set were either eliminated or combined as illustrated in Tables 2 and 3 . The combinations resulted in 9 potential gear groups, 8 country groups and 5 tonnage class categories. Catches associated with gear and country categories excluded from the effort standardization analyses were subsequently incorporated when estimates of standardized fishing effort and catch per unit effort (CPUE) were expanded to total catch. A standard category was chosen for each factor as follows: gear - otter trawl, bottom (side); tonnage class - 3; and, country - USA. Units of fishing effort used in the analyses were expressed as hours fished; since effort for the USA fleet is reported as days fished (equivalent to $24 \mathrm{hr}$ of fishing time), USA effort was multiplied by a factor of 24 to furnish effort units consistent with all other fleets.

The Northeast Fisheries Science Center has conducted stratified random bottom trawl surveys in the offshore waters of the Northwest Atlantic since autumn 1963 and spring 1968. Detailed descriptions of sampling design, methodology and applications of the survey are provided by Grosslein (1969), Clark (1979) and Almeida et al. (MS 1986). Species-specific data from 1963-1988 surveys were aggregated into four categories for analysis: (1) Principal groundfish, including those species of major importance in the Georges Bank commercial fishery; (2) Other groundfish, those species comprising the remainder of the demersal component of the system; (3) Principal pelagics, including mackerel and sea herring; and (4) Elasmobranchs, in- 
TABLE 2. Gear groupings used in effort standardization analyses.

\begin{tabular}{|c|c|c|c|}
\hline $\begin{array}{l}\text { Gear } \\
\text { code }\end{array}$ & Gear group & & Gears included \\
\hline 11 & Otter Trawl, Bottom (Side) & OTB-1 & Otter Trawl, Bottom (Side) \\
\hline 12 & Otter Trawl, Bottom (Stern) & OTB-2 & Otter Trawl, Bottom (Stern) \\
\hline 13 & Midwater Trawls & $\begin{array}{l}\text { OTM } \\
\text { OTM-1 } \\
\text { OTM-2 } \\
\text { PTM }\end{array}$ & $\begin{array}{l}\text { Midwater Trawl } \\
\text { Midwater Trawl (Side) } \\
\text { Midwater Trawl (Stern) } \\
\text { Midwater Pair Trawl }\end{array}$ \\
\hline 16 & Miscellaneous Trawls & $\begin{array}{l}\text { PTB } \\
\text { SND } \\
\text { SSC }\end{array}$ & $\begin{array}{l}\text { Pair Trawl, Bottom } \\
\text { Danish Seine } \\
\text { Scottish Seine }\end{array}$ \\
\hline 31 & Purse Seine & PS & Purse Seine \\
\hline 41 & Gill Nets & $\begin{array}{l}\text { GNS } \\
\text { GND }\end{array}$ & $\begin{array}{l}\text { Set Gillnets } \\
\text { Drift Gillnets }\end{array}$ \\
\hline 51 & Line Gear & $\begin{array}{l}\text { LL } \\
\text { LLS } \\
\text { LLD } \\
\text { LHP } \\
\text { LTL }\end{array}$ & $\begin{array}{l}\text { Longlines } \\
\text { Set Lines } \\
\text { Drift Lines } \\
\text { Hand Lines } \\
\text { Troll Lines }\end{array}$ \\
\hline 60 & Fixed Gear & $\begin{array}{l}\text { FIX } \\
\text { FPN } \\
\text { FPO } \\
\text { FWR }\end{array}$ & $\begin{array}{l}\text { Traps } \\
\text { Uncovered Pound Nets } \\
\text { Covered Pots } \\
\text { Weirs }\end{array}$ \\
\hline 71 & Dredges & $\begin{array}{l}\text { DRB } \\
\text { DRH }\end{array}$ & $\begin{array}{l}\text { Dredge (boat) } \\
\text { Dredge (hand) }\end{array}$ \\
\hline
\end{tabular}

Note: Gear deleted from all analyses includes: beach seine; squid jiggers; all traps, pound nets, pots and weirs; all dredge gear; harpoons; and all miscellaneous or unknown gear.

Gear further deleted from demersal effort analyses includes: purse seines and all midwater trawls.

cluding dogfish and skate species. Stratified mean weight-per-tow $(\mathrm{kg})$ indices were then calculated for each aggregate group inclusive of strata 5 through 25. A complete listing of the species within each of the groups is given in Table 4 .

\section{Effort standardization}

Relative harvesting efficiency varies markedly among different vessel size classes and fishing gears. To account for these differences, nominal fishing effort was standardized using a general linear model approach (e.g. Robson, 1966; Gavaris, 1980; Kimura, 1981; 1988) based on the multiplicative model:

$$
U_{i j k l}=\alpha_{i} \beta_{j} \delta_{k}(q B) \exp \left(\varepsilon_{i j k}\right)
$$

where $U_{i j k l}$ is the CPUE for the ith gear, $j^{\text {th }}$ tonnage class, kth country, and Ith observation; $\alpha_{i}, \beta$, and $\delta_{k}$ represent gear, tonnage class and country effects respectively, $\mathrm{q}$ is the catchability coefficient, $\mathrm{B}$ represents mean population biomass and $\varepsilon_{\mathrm{ijkl}}$ is a normally distributed random variable with mean 0 and constant variance. Because the population biomass is not directly known, the term qB is replaced by the mean CPUE $(\mu)$ and all coefficients are estimated relative to an arbitrarily defined standard (described previously). Least squares estimates of the model coefficients were made under the constraints: $\Sigma \log _{e} \alpha_{i}=\Sigma \log _{e} \beta_{j}=\Sigma \log _{e} \delta_{k}=0$ for the linearized model:

$$
\log _{e} U_{i j k l}=\log _{e} \mu+\log _{e} \alpha_{i}+\log _{e} \beta_{j}+\log _{e} \delta_{k}+\varepsilon_{i j k l}
$$

Retransformation of the model coefficients to linear scale was made after correction for bias following Granger and Newbold, (1977). Interactions among all main effects in the model were tested, and several interactions were found to be statis- 
TABLE 3. Country groupings and tonnage class categories used in effort standardization analyses.

\begin{tabular}{|c|c|c|c|c|c|}
\hline $\begin{array}{l}\text { Country } \\
\text { code }\end{array}$ & $\begin{array}{l}\text { Country } \\
\text { group }\end{array}$ & $\begin{array}{l}\text { Countries } \\
\text { included }\end{array}$ & $\begin{array}{l}\text { Tonnage } \\
\text { code }\end{array}$ & $\begin{array}{l}\text { Tonnage } \\
\text { classes }\end{array}$ & $\begin{array}{c}\mathrm{GRT} \\
\text { range }\end{array}$ \\
\hline \multirow[t]{4}{*}{01} & Bulgaria (BUL) & $\begin{array}{l}\text { Bulgaria } \\
\text { Romania }\end{array}$ & 2 & 2 & $0-49.9$ \\
\hline & & USSR & 3 & 3 & $50-149.9$ \\
\hline & & Cuba & & & \\
\hline & & & 4 & 4 & $150-499.9$ \\
\hline \multirow[t]{4}{*}{02} & Canada (CAN) & Can-MQ & & & \\
\hline & & Can-M & 5 & 5 & 500-999.9 \\
\hline & & Can-Q & & & \\
\hline & & Can-N & 6 & 6 and 7 & 1000 \& over \\
\hline 10 & $\begin{array}{l}\text { Federal Republic of } \\
\text { of Germany (FRG) }\end{array}$ & $\begin{array}{l}\text { FRG } \\
\text { France (M) }\end{array}$ & & & \\
\hline 11 & $\begin{array}{l}\text { German Democratic } \\
\text { Republic (GDR) }\end{array}$ & GDR & & & \\
\hline 14 & Japan (JPN) & Japan & & & \\
\hline 16 & Poland (POL) & Poland & & & \\
\hline 19 & Spain (ESP) & $\begin{array}{l}\text { Spain } \\
\text { Italy }\end{array}$ & & & \\
\hline 22 & United States (USA) & USA & & & \\
\hline
\end{tabular}

tically significant. However, in each case, the proportion of the variance explained by the interaction terms was small relative to the main effects $(<7 \%)$. Accordingly, only main effects models were considered in subsequent analyses. The large number of degrees of freedom in the model increased the probability of detecting significant interactions, but the practical significance of these interactions seemed to be minor.

Standardized effort for each country-gear-tonnage class category was estimated by multiplying nominal effort by the product of the coefficients for each factor. Estimated effort was then accumulated over all categories on an annual basis and the annual effort adjusted up to account for catches which were excluded from the standardization procedure. The annual adjustments generally represented less than $10 \%$ of the total annual landings.

We also examined models incorporating a year effect and a covariate based on research vessel surveys conducted by the Northeast Fisheries Science Center to account for the effects of learning (in the early years of the multinational fishery) and the effects of technological changes not directly quantifiable in the model (e.g. satellite navigation systems, etc.). Estimates of stratified mean catch per tow $(\mathrm{kg})$ for each species group were made after the survey catch data were transformed to natural logarithms; retransformed values (with bias correction) were obtained using procedures outlined by Bliss (1967). Autumn survey data were used for the principal groundfish and other groundfish groups while spring data were used for principal pelagics and elasmobranchs to account for seasonal changes in availability. The general linear model with covariate term is:

$$
\begin{aligned}
\log _{e} u_{i j k l m}= & \log _{e} u+\log _{e} \alpha_{i}+\log _{e} \beta_{j}+\log _{e} \delta_{k}+ \\
& \log _{e} \gamma+\log _{e} l_{1}+\varepsilon_{i j k l m}
\end{aligned}
$$

where $\gamma$ is the coefficient for the survey biomass term (P) for the principal groundfish group, $h_{1}$ is the year effect coefficient, and all other terms are defined as before. Interaction terms were again tested and found to explain only a small fraction of the variance. Accordingly, the final model included only main effects.

\section{Results}

\section{Standardization of fishing efort}

Results from the linear model analyses for the demersal + pelagic groups and the demersals-only are given in Tables 5 through 7 . Both analyses, the 
TABLE 4. Species included in aggregate groups from bottom trawl surveys.

\begin{tabular}{|c|c|}
\hline \multicolumn{2}{|c|}{ Principal Groundfish } \\
\hline Haddock & Melanogrammus aeglefinus \\
\hline Atlantic cod & Gadus morhua \\
\hline Pollock & Pollachius virens \\
\hline Redfish & Sebastes spp. \\
\hline Silver hake & Merluccius bilinearis \\
\hline Red hake & Urophycis chuss \\
\hline Yellowtail flounder & Pleuronectes ferrugineus \\
\hline Summer flounder & Paralichthys dentatus \\
\hline Winter flounder & Pleuronectes americanus \\
\hline American plaice & Hippoglossoides platessoides \\
\hline Witch flounder & Glyptocephalus cynoglossus \\
\hline \multicolumn{2}{|c|}{ Other Groundfish } \\
\hline White hake & Urophycis tenuis \\
\hline Ocean pout & Macrozoarces americanus \\
\hline American goosefish & Lophius americanus \\
\hline Cusk & Brosme brosme \\
\hline Windowpane flounder & Scophthalmus aquosus \\
\hline Northern sea robin & Prionotus carolinus \\
\hline Striped sea robin & Prionotus evolans \\
\hline Armored sea robin & Peristedion miniatum \\
\hline Hookeared sculpin & Artediellus uncinatus \\
\hline Longhorned sculpin & Myoxocephalus octodecemspinosus \\
\hline Mailed sculpin & Triglops ommatistius \\
\hline Sea raven & Hemitripterus americanus \\
\hline Wolffish & Anarhichas lupus \\
\hline \multicolumn{2}{|c|}{ Principal Pelagics } \\
\hline Atlantic mackerel & Scomber scombrus \\
\hline Sea herring & Clupea harengus \\
\hline \multicolumn{2}{|c|}{ Elasmobranchs } \\
\hline Spiny dogfish & Squalus acanthias \\
\hline Smooth dogfish & Mustelus canis \\
\hline Little skate & Raja erinacea \\
\hline Winter skate & Raja ocellata \\
\hline Thorny skate & Raja radiata \\
\hline Barndoor skate & Raja laevis \\
\hline Clearnose skate & Raja eglanteria \\
\hline Leopard skate & Raja garmani \\
\hline Smoothtailed skate & Raja senta \\
\hline
\end{tabular}

TABLE 5. Linear model for NAFO effort (hrs) data standardization for groundfish, flounders and small pelagic groups using USA, Ton Class 3, Side Trawl standard data with No Year Effect.

\begin{tabular}{lrcccc}
\hline \hline Source & \multicolumn{1}{c}{ DF } & Sum of squares & Mean square & F value & PR $>$ F \\
\hline Model & 17 & 2310.00 & 135.88 & 184.16 & 0.0 \\
Gear & 6 & 1013.64 & 168.94 & 228.97 & 0.0 \\
Ton Class & 4 & 700.90 & 175.23 & 237.49 & 0.0 \\
Country & 7 & 595.46 & 85.07 & 115.29 & 0.0 \\
Error & 2455 & 1811.38 & 0.74 & & \\
Total & 2472 & 4121.38 & & & \\
\hline
\end{tabular}


TABLE 6. Linear model for NAFO effort (hrs) data standardization for directed groundfish and flounder fisheries using USA, Ton Class 3, Side Trawl - Standard data with No Year Effect.

\begin{tabular}{lrrrrr}
\hline \hline Source & \multicolumn{1}{c}{ DF } & Sum of squares & Mean square & F value & PR $>$ F \\
\hline Model & 15 & 1241.38 & 82.76 & 130.43 & 0.0 \\
Gear & 4 & 196.85 & 49.21 & 77.56 & 0.0 \\
Ton Class & 4 & 437.84 & 109.46 & 172.51 & 0.0 \\
Country & 7 & 606.69 & 86.67 & 136.59 & 0.0 \\
Error & 2043 & 1296.30 & 0.63 & & \\
Total & 2058 & 2537.68 & & & \\
\hline
\end{tabular}

TABLE 7. Linear model for NAFO effort (hrs) data standardization for directed groundfish and flounder fisheries using USA, Ton Class 3, Side Trawl, 1963 - Standard; Survey Index as covariate.

\begin{tabular}{lrrrrr}
\hline Source & \multicolumn{1}{c}{ DF } & Sum of squares & Mean square & F value & PR $>$ F \\
\hline Model & 38 & 1357.34 & 35.72 & 61.41 & 0.0 \\
Surv. Index & 1 & 199.51 & 199.51 & 343.00 & 0.0 \\
Year & 22 & 133.13 & 6.05 & 10.40 & 0.0 \\
Gear & 4 & 202.71 & 50.68 & 87.13 & 0.0 \\
Ton Class & 4 & 295.07 & 73.77 & 126.82 & 0.0 \\
Country & 7 & 526.93 & 75.28 & 129.41 & 0.0 \\
Error & 2005 & 1166.22 & 0.58 & & \\
Total & 2043 & 2523.57 & & & \\
\hline
\end{tabular}

three-factor model (Tables 5 and 6) and the model which incorporated the survey index as a covariate (Table 7), accounted for approximately $50-55 \%$ of the total sums of squares. For each data set, the gear, tonnage class and country effects were highly significant $(P<0.01)$, and year was highly significant in the covariate model. The only interactions found to be significant $(P<0.05)$ were gear-country and then only between fixed gear fished by Canada and the USA. In general, the contribution of the interaction terms to the model sums of squares was minimal.

Coefficients for the gear, tonnage class and country effects, converted to a linear scale, are given in Table 8. Relative to the side trawl standard, gear coefficients were highest for pelagic gear (midwater trawls and purse seines) and lowest for fixed gear (gill nets and line gear). Tonnage class coefficients generally increased with vessel size, the class $6+7$ category being approximately twice the class 3 standard. Country coefficients were variable with most country groups exhibiting a 2-to 4-fold difference in fishing power relative to the USA standard. Country coefficients were generally highest for the combined demersal + pelagic group analysis compared to the demersals-only analyses. The largest differences occurred in the FRG/France, GDR and Polish fleets, suggesting that higher catch rates were achieved by these countries in the pelagic fisheries. Between 1966 and 1976, pelagic species (principally herring and mackerel) accounted for over $80 \%$ of the total catch by these countries (Appendix 1).

\section{Trends in nominal and standardized fishing effort and CPUE}

Nominal fishing effort on Georges Bank for the combined demersal and pelagic gear components increased rapidly during the 1960s, peaking at about 947000 hrs fished in 1965 (Table 9, Fig. 3). Total effort subsequently declined to less than 500000 hrs in 1977 and 1978, before increasing to over 850000 hrs in 1985. Total nominal effort declined slightly thereafter, but remained relatively high through 1987. Nominal effort trends for the demersal fishery follow those for the total fishery, with a peak level of $939000 \mathrm{hr}$ in 1965 followed by gradual decline and subsequent increase (Table 9 , Fig. 3).

Trends in standardized effort differ considerably from nominal effort, particularly during the mid1970s. Standardized effort (Table 9, Fig. 4) increased from about $616000 \mathrm{hr}$ fished in 1960 to about 2400000 hrs in 1969 and remained relatively high, increasing to a peak of over 3000000 hrs in 
TABLE 8. Standardization coefficients for gear, tonnage class and country effects (linear scale) derived from NAFO effort data standardization analyses.

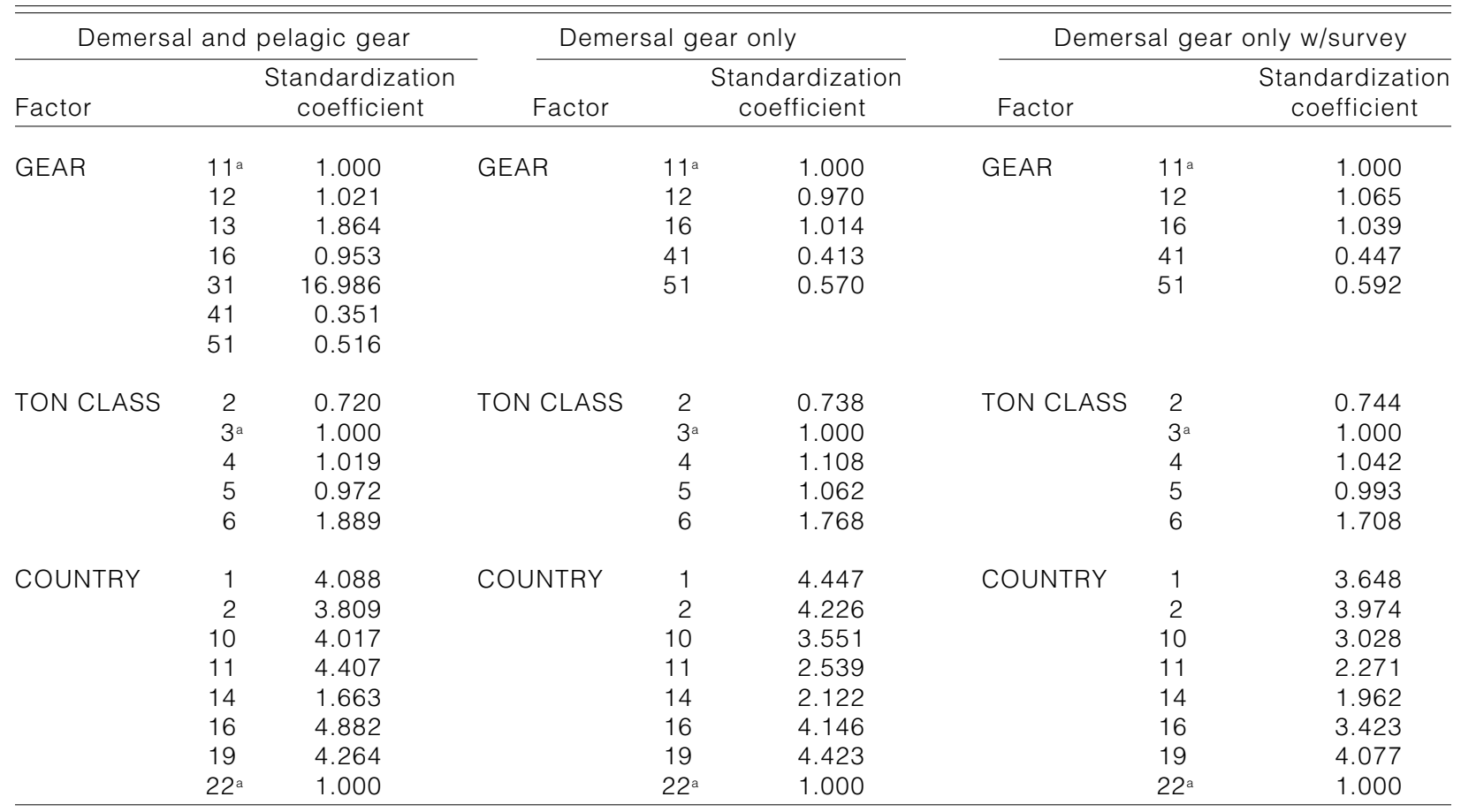

aDenotes standard gear, tonnage class and country categories.

TABLE 9. Total catch (metric tons, live), nominal effort (hrs) and CPUE (tons/hr), and estimated standardized effort (hrs) and CPUE (tons/hr) derived from General Linear Models (GLM) for Georges Bank (NAFO Div. 5Z), 1960-19871.

\begin{tabular}{|c|c|c|c|c|c|c|c|c|c|c|c|c|}
\hline \multirow[b]{4}{*}{ Year } & \multicolumn{5}{|c|}{ Demersal and small pelagic fishery } & \multicolumn{7}{|c|}{ Demersal fishery only } \\
\hline & \multirow{3}{*}{$\begin{array}{l}\text { Total } \\
\text { catch }\end{array}$} & \multirow{3}{*}{$\begin{array}{c}\text { Nominal } \\
\text { effort }\end{array}$} & \multirow{3}{*}{$\begin{array}{l}\text { Nominal } \\
\text { CPUE }\end{array}$} & \multirow{3}{*}{$\begin{array}{c}\text { Standard } \\
\text { Effort }\end{array}$} & \multirow{3}{*}{$\begin{array}{l}\text { (wi } \\
\text { Standard } \\
\text { CPUE }\end{array}$} & \multirow{3}{*}{$\begin{array}{l}\text { ut survey } \\
\text { Total } \\
\text { catch }\end{array}$} & \multirow{3}{*}{$\begin{array}{c}\text { Nox as cova } \\
\text { Nominal } \\
\text { effort }\end{array}$} & \multirow{3}{*}{$\begin{array}{l}\text { Nomiate) } \\
\text { CPUE }\end{array}$} & \multicolumn{3}{|c|}{ (with covariate added) } & \multirow{3}{*}{$\begin{array}{c}\text { Standard } \\
\text { CPUE }\end{array}$} \\
\hline & & & & & & & & & Standard & Standard & Standard & \\
\hline & & & & & & & & & effort & CPUE & effort & \\
\hline 1960 & 147646 & 607528 & 0.2430 & 616208 & 0.2396 & 147646 & 607528 & 0.2430 & 628541 & 0.2349 & - & - \\
\hline 1961 & 204670 & 517627 & 0.3954 & 697772 & 0.2933 & 133372 & 502246 & 0.2656 & 476548 & 0.2799 & - & - \\
\hline 1962 & 371277 & - & - & - & - & 214259 & - & - & - & - & - & - \\
\hline 1963 & 414411 & 698108 & 0.5936 & 1166433 & 0.3553 & 310756 & 649020 & 0.4788 & 1050207 & 0.2959 & 960925 & 0.3234 \\
\hline 1964 & 540108 & 799251 & 0.6758 & 1577834 & 0.3423 & 404763 & 711375 & 0.5690 & 1359747 & 0.2977 & 1325530 & 0.3054 \\
\hline 1965 & 716238 & 946743 & 0.7565 & 2201576 & 0.3253 & 671209 & 939265 & 0.7146 & 2280163 & 0.2944 & 2357651 & 0.2847 \\
\hline 1966 & 688117 & 931664 & 0.7386 & 2254374 & 0.3052 & 540582 & 863428 & 0.6261 & 2115709 & 0.2555 & 2895930 & 0.1867 \\
\hline 1967 & 545758 & 792021 & 0.6891 & 1729752 & 0.3155 & 315893 & 646700 & 0.4885 & 1294141 & 0.2441 & 1668625 & 0.1893 \\
\hline 1968 & 689547 & 794644 & 0.8677 & 2088348 & 0.3302 & 292579 & 568448 & 0.5147 & 1148756 & 0.2547 & 1732244 & 0.1689 \\
\hline 1969 & 708457 & 753560 & 0.9401 & 2398317 & 0.2954 & 371741 & 574676 & 0.6469 & 1464832 & 0.2538 & 1945758 & 0.1911 \\
\hline 1970 & 516986 & 629448 & 0.8213 & 1590878 & 0.3250 & 195811 & 494735 & 0.3958 & 859045 & 0.2279 & 1103990 & 0.1774 \\
\hline 1971 & 649293 & 692419 & 0.9377 & 2218866 & 0.2926 & 300944 & 568851 & 0.5290 & 1439060 & 0.2091 & 1755734 & 0.1714 \\
\hline 1972 & 741558 & 772478 & 0.9600 & 2918940 & 0.2541 & 375331 & 606055 & 0.6193 & 1757841 & 0.2135 & 1715208 & 0.2188 \\
\hline 1973 & 879822 & 706430 & 1.2454 & 2511851 & 0.3503 & 342305 & 590345 & 0.5798 & 1597036 & 0.2143 & 1595149 & 0.2146 \\
\hline 1974 & 607416 & 702114 & 0.8651 & 2144174 & 0.2833 & 281183 & 612661 & 0.4590 & 1352889 & 0.2078 & 1885828 & 0.1491 \\
\hline 1975 & 550607 & 762818 & 0.7218 & 3055377 & 0.1802 & 104918 & 582053 & 0.1803 & 755237 & 0.1389 & 798116 & 0.1315 \\
\hline 1976 & 361337 & 575528 & 0.6278 & 1686101 & 0.2143 & 115092 & 500667 & 0.2299 & 695764 & 0.1654 & 606348 & 0.1898 \\
\hline 1977 & 171057 & 475045 & 0.3601 & 738798 & 0.2315 & 154634 & 466850 & 0.3312 & 688171 & 0.2247 & 825958 & 0.1872 \\
\hline 1978 & 157223 & 499598 & 0.3147 & 707588 & 0.2222 & 133634 & 489364 & 0.2731 & 624523 & 0.2140 & 773897 & 0.1727 \\
\hline 1979 & 145713 & 538814 & 0.2704 & 588869 & 0.2474 & 127957 & 531541 & 0.2407 & 582323 & 0.2197 & 761473 & 0.1680 \\
\hline 1980 & 176161 & 571845 & 0.3081 & 767239 & 0.2296 & 145413 & 554749 & 0.2621 & 631577 & 0.2302 & 808033 & 0.1800 \\
\hline 1981 & 187820 & - & - & - & - & 151476 & - & - & - & - & - & - \\
\hline 1982 & 184629 & 702785 & 0.2627 & 857745 & 0.2152 & 169434 & 687414 & 0.2465 & 824583 & 0.2055 & 1044790 & 0.1622 \\
\hline 1983 & 156592 & 756616 & 0.2070 & 830749 & 0.1885 & 150457 & 745931 & 0.2017 & 812176 & 0.1853 & 943002 & 0.1596 \\
\hline 1984 & 134891 & 804254 & 0.1677 & 869060 & 0.1552 & 121597 & 792322 & 0.1535 & 846472 & 0.1437 & 1147163 & 0.1060 \\
\hline 1985 & 112772 & 853776 & 0.1321 & 949373 & 0.1188 & 102693 & 838985 & 0.1224 & 907611 & 0.1131 & 920342 & 0.1116 \\
\hline 1986 & 98810 & 717216 & 0.1378 & 787517 & 0.1255 & 84062 & 706275 & 0.1190 & 759930 & 0.1106 & 779195 & 0.1079 \\
\hline 1987 & 108464 & 829505 & 0.1308 & 886702 & 0.1223 & 93026 & 816350 & 0.1140 & 888859 & 0.1047 & 952641 & 0.0977 \\
\hline
\end{tabular}

1 Data for 1962 and 1981 were eliminated from analyses because of inconsistencies (see text for explanation). 


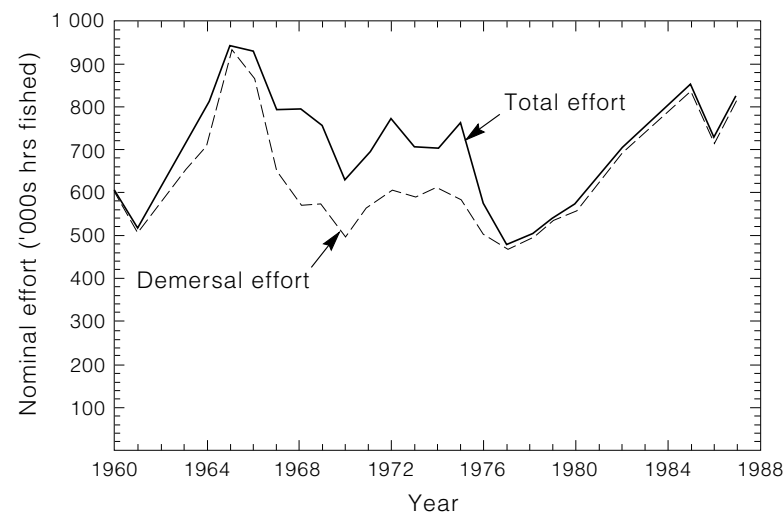

Fig. 3. Total nominal fishing effort and nominal effort on demersals on Georges Bank (NAFO Div. 5Z), 1960-87. Effort data for 1962 and 1981 have been excluded because of statistical discrepancies.

1975. Effort declined sharply in 1976 and 1977, and continued to decline to less than $600000 \mathrm{hrs}$ in 1979. Although total effort increased to about 950 $000 \mathrm{hrs}$ in 1985 and has generally remained above 800000 hrs since 1982, recent effort levels have remained well below those recorded during the mid-1970s.

Trends in standardized effort for the demersal component were quite distinct from the overall standardized effort pattern, with major declines in effort evident throughout the late-1960s and continuing through the mid-1970s. This difference may be explained by increases in the amount of off-bottom gear, as indicated by trends in pelagic catches (Fig. 2) and nominal effort (Fig. 3), but is accentuated by the relatively high coefficients for purse seine gear (16.99) relative to the standard (Table 8). Standardized effort trends for both components are similar after 1977, when effort was primarily by USA vessels fishing with bottom trawls. When the survey index is included in the model as a covariate to account for changes in abundance, demersal effort remained at a relatively high level for a longer period during the late-1960s than indicated by the standard model (Table 9, Fig. 4). The covariate model also indicated slightly greater demersal effort during the late-1970s and early-1980s.

Standardized CPUE for the combined demersal and pelagic gear components increased from 0.24 tons/hr fished in 1960 to 0.36 tons/hr in 1963 (Table 9 , Fig. 5) but declined gradually thereafter to about 0.18 tons/hr in 1975. After increasing to about 0.25 tons/hr in 1979, the combined CPUE index began to decline rapidly, reaching record low levels of about 0.12 tons/hr between 1985 and 1987. CPUE for the demersal component followed the same pattern as

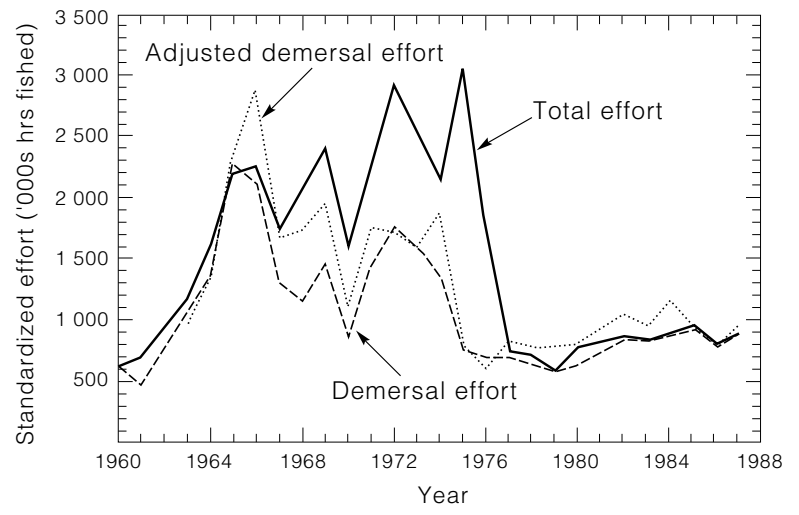

Fig. 4. Standardized effort on total fishing and demersal gear, and standardized demersal gear effort adjusted for survey biomass index on Georges Bank (NAFO Div. 5Z), 1960-87. Standardized effort was not calculated for 1962 and 1981 due to nominal effort discrepancies in the 2 years.

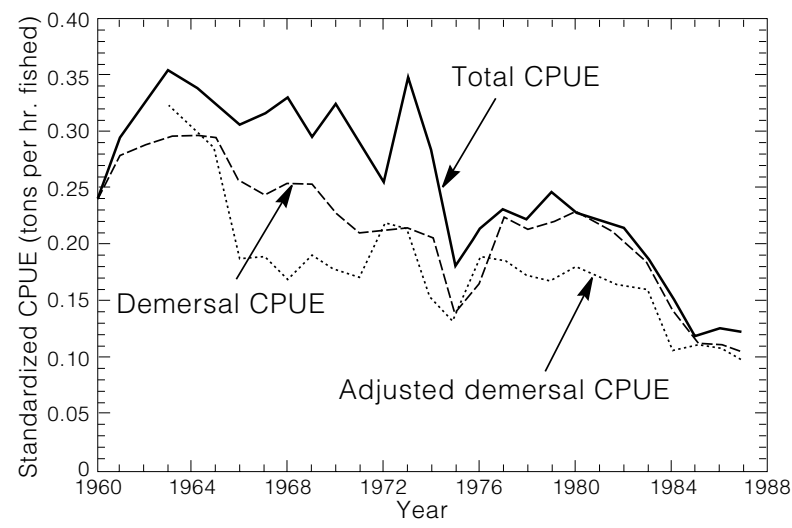

Fig. 5. Total standardized nominal catch-per-hr fished (CPUE), for all gear (demersal and pelagic), for demersal gear alone, and for demersal gear effort adjusted for survey biomass index on Georges Bank (NAFO Div. 5Z), 1960-87. CPUE values were not calculated for 1962 and 1981 due to nominal effort discrepancies in the 2 years.

the combined index, declining from a maximum of 0.30 tons/hr during $1963-65$ to about 0.15 tons/hr in 1975 and 1976 (Table 9, Fig. 5). During the late1970s, demersal CPUE increased steadily but declined after 1980 to about 0.10 tons/hr during 198587. However, when the survey index was incorporated as a covariate in the model, the decline in CPUE during the mid-1960s was even more pronounced, and the apparent increase in CPUE during the late-1970s less evident.

\section{Yield-effort trajectory}

During the initial phase of exploitation by the distant water fleets, aggregate yield increased 
sharply as total effort increased, and previously unexploited or lightly exploited species were harvested (Fig. 6A). However, by 1976, both yield and total effort had declined, reflecting reduced abundance of several important species including haddock and herring. With the implementation of extended jurisdiction in 1977, total standardized effort was reduced to pre-impact levels (Fig. 6A). The yield-effort trajectory for the period dominated by the distant water fleets reflects several distinct stanzas in fishery development ranging from an initial concentration on demersal species to a subsequent focus on pelagic species (primarily herring and mackerel). These shifts in target species appear to have been largely opportunistic and keyed to the occurrence of dominant year-classes.

Total fishing effort by the domestic fleet since implementation of extended jurisdiction has not approached levels observed during the peak of the distant water fisheries. Despite reduced effort levels under MFCMA, however, yield has remained at relatively low levels. The lower aggregate yield since 1977 reflects both the reduced abundance of principal groundfish and a difference in the species composition of the fishery. Fishing effort is currently more sharply focused on the traditionally exploited groundfish and flounder complex.

Standardized fishing effort in the demersal component of the fishery increased steadily from 1963 to 1966 , peaking with concentration on the exceptional 1963 year-class of haddock (Fig. 6B). Directed effort on demersal species subsequently declined with the sharp decrease in haddock biomass. By 1976, effort levels in the demersal component had declined to pre-distant water fleet levels. Following the implementation of extended jurisdiction, the yield effort trajectory has remained within a more limited domain relative to its earlier history.

\section{Trends in survey biomass estimates}

The aggregate biomass index for principal groundfish peaked in 1964 (102.2 kg/tow) but declined thereafter, reaching a record-low of $17.1 \mathrm{~kg} /$ tow in 1974, an 83\% reduction from the 1964 level (Fig. 7A). Sharp declines in abundance of haddock, silver hake, redfish and yellowtail flounder occurred during this period. The biomass index increased again to an average of $51.0 \mathrm{~kg} /$ tow during 1976-78, but subsequently declined to an average of $17.9 \mathrm{~kg} /$ tow during 1984-88, its lowest level since 1974. The biomass index for other groundfish remained relatively high during 1963-66, averaging $11.6 \mathrm{~kg} /$ tow, but declined during 1967-71 (Fig. 7B). The index increased steadily during the late-1970s, reaching peak levels of about $20 \mathrm{~kg} /$ tow in 1980 and 1985 , but subsequently declined to levels observed

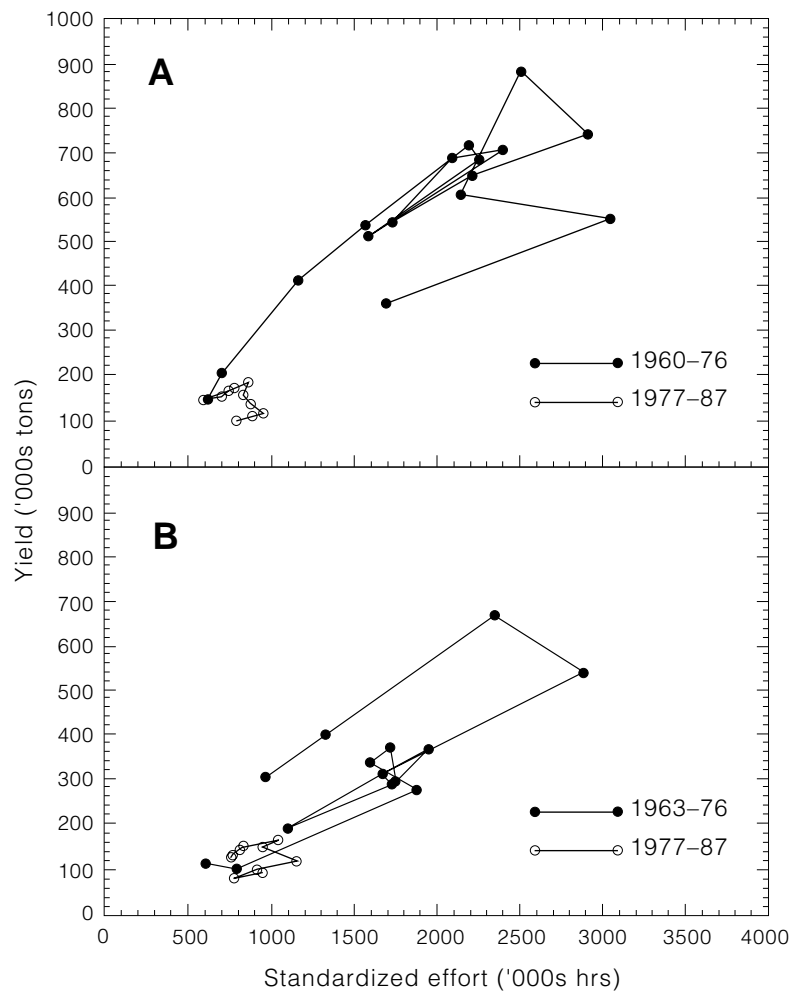

Fig. 6. Time trajectories of yield $v s$ fishing effort for Georges Bank, 1960-76 and 1977-87. (A) Total pelagic and demersal catch $v s$ standardized total effort, and (B) Demersal catch vs standardized demersal effort adjusted by NEFSC bottom trawl survey biomass indices from 1963 to 1987.

in the mid-1960s.

The aggregate biomass index for principal pelagics fluctuated during the late-1960s and early1970s, but declined sharply after 1973 due to reduced abundance of Atlantic mackerel and the collapse of the Georges Bank herring stock in 1977 (Fig. 7C). Pelagic biomass has been increasing since 1985 due to significant rebuilding of the mackerel stock and the resurgence of the herring population on Georges Bank (Smith and Morse, MS 1990). Evidence of recovery of this population has been obtained based on bottom trawl and ichthyoplankton surveys and by-catch rates in groundfish fisheries directed at silver hake.

Elasmobranch biomass, which remained relatively low throughout most of the 1970s increased sharply during the 1980s (Fig. 7D). By 1988, elasmobranch biomass had increased by a factor of 25 over pre-1980 levels, due to sharp and sustained increases in spiny dogfish and skate populations.

\section{Discussion}

The arrival of distant water fleets on Georges 


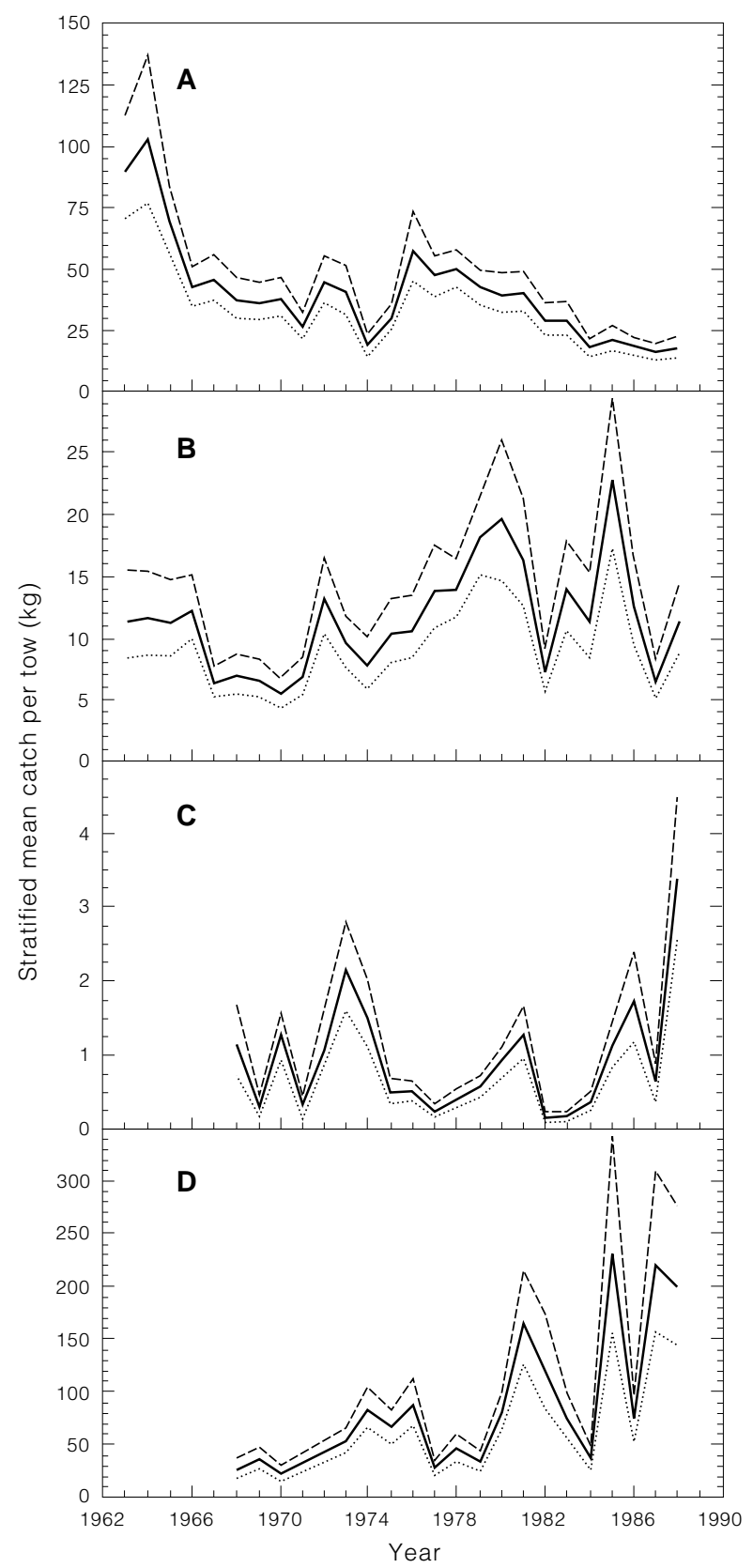

Fig. 7. NEFSC bottom trawl survey biomass indices and 95\% confidence intervals for (A) 'principal groundfish', (B) 'other groundfish', (C) 'principal pelagics' (mackerel and herring), and (D) 'elasmobranchs' on Georges Bank (NAFO Div. 5Z; NEFSC offshore sampling strata 5-25), 1963-88. (A) and (B) from autumn surveys; (C) and (D) from spring surveys.

Bank in the early-1960s resulted in a large-scale escalation of fishing effort and caused major perturbations to the structure of the system. The nearly four-fold increase in standardized fishing effort during the period 1960-72 induced sharp declines in aggregate fish biomass as measured by commercial catch rates and research vessel biomass indices. Our estimates of trends in standardized fishing effort on Georges Bank between 1960 and 1972 parallel those provided by Brown et al. (1976) for the entire Subarea 5-Statistical Area 6 region. After 1972, fishing effort remained relatively high on Georges Bank until 1977 when extended jurisdiction sharply curtailed distant water fleet fishing activity. As a result, fishing effort on pelagic species (herring and mackerel) was sharply reduced, and from 1977 onward effort on Georges Bank has been directed toward the demersal component primarily by USA and Canadian otter trawlers. Thus, trends in nominal effort, standardized effort and standardized CPUE have been essentially the same since 1977 for the combined pelagic and demersal components as for the demersal component alone.

The sharp increase in CPUE between 1960 and 1965 occurred during a period of increasing effort and yield, although the five-fold increase in the catch of finfish and squids was accomplished with a 3.5-fold increase in estimated standardized fishing effort. This suggests that the abundance of principal groundfish and pelagics was increasing, although results from bottom trawl surveys suggest a declining trend after 1964 for the principal groundfish. However, sharp increases in biomass of herring and haddock occurred between 1960 and 1963 prior to the beginning of the NEFSC survey time series. Thus, the large 1960 year-class of herring (Anthony and Waring, 1980) and the exceptional 1963 year-class of haddock (Clark et al., 1982) must have contributed to the substantial increase in stock biomass indicated by the CPUE index through at least 1964. It is also likely, however, that the increase in the estimated CPUE during the early 1960s resulted, to some extent, from increased fleet efficiency as suggested by Brown et al. (1976), since fisheries prosecuted by the distant water fleets were then in a development stage.

This increased fleet efficiency was modelled by Brown et al. (1976) using a learning function, which they defined as "... a monotonically increasing function of CPUE through a continuous time period which was not caused by changes in stock abundance...", applied over the first 3 years of a fleet's participation in the fishery. The rate of learning was determined by comparing observed CPUE with predicted values adjusted by independent abundance estimates derived from autumn bottom trawl surveys.

Our approach to adjusting the standardized demersal effort to account for changes in fleet efficiency differs from Brown et al. (1976) only in the application of the fishery-independent estimates of 
abundance as covariates in the General Linear Model. Our CPUE adjustments reflect differences in the change in commercial CPUE over time relative to the changes in the survey biomass index. Both approaches, however, suggest that the decline in biomass which followed the peak levels of the early-1960s was more severe than would be predicted without the adjustment for increased fleet efficiency. Our analysis further suggests that the apparent increase in CPUE during the late-1970s and early-1980s may have also been partially due to technological advancements, since significant improvements in vessel design, gear and electronics occurred throughout the USA fleet during this period.

The decline in CPUE since the mid-1960s reflects the overall decline in abundance of principal groundfish and pelagics, including haddock, silver hake, herring and mackerel. The secondary increase in CPUE which occurred during the late1970 s coincided with increased abundance of several stocks of groundfish and flounders, including haddock, cod, pollock and yellowtail flounder, following recruitment of several relatively strong yearclasses between 1975 and 1980 (Clark et al., MS 1982; MS 1984; Mayo et al.,1989; Serchuk and Wigley,1992). The decline in CPUE since 1982 is associated with increased fishing mortality on these same stocks (U.S. Department of Commerce, 1988).

Based on their standardized fishing effort estimates, Brown et al. (1976) computed a $65 \%$ decline in commercial CPUE in Subarea 5 and Statistical Area 6 between 1963 and 1972. Our results suggest declines of $50 \%$ for all finfish and $60 \%$ for the demersal component in Div. $5 Z$ alone during a similar period. CPUE for both components, after increasing slightly between 1978 and 1982, declined to record-low levels after 1984, 65-70\% below those in 1963.

Parallel declines in research vessel survey indices were noted during this period. The aggregate biomass index for principal groundfish declined precipitously during 1964-66, reflecting a major reduction in haddock abundance. Other groundfish species also decreased during the period as a result of large incidental by-catches and the reduction fisheries prosecuted by many of the international fleets. Survey biomass indices for dogfish and skates remained relatively low during the peak years of the distant water fisheries since these species were also harvested incidentally and taken for reduction.

In the years prior to and shortly after the enactment of the MFCMA, relative biomass levels of principal groundfish and other groundfish began to increase. Brown and Halliday (1983) suggested that the recovery of groundfish stocks during this period was related to reduced fishing pressure which resulted from a combination of more restrictive ICNAF TAC regulations and the extension of jurisdiction by coastal states. We can now see that the recovery on Georges Bank was short-lived, however, and soon reversed as effort by domestic vessels increased; biomass of principal groundfish declined throughout the 1980s, reaching an historic low level in 1988. We note, however, that the high biomass levels for this group during the mid-1960s largely reflect haddock abundance, particularly the dominant 1963 year-class, and that the aggregate biomass indices for this period do not necessarily represent average conditions. The most striking changes in relative biomass indices during the past three decades are those for elasmobranchs and the principal pelagics. Skate and dogfish species have increased 2-to 5-fold since the late-1970s. Herring and mackerel biomass indices have increased substantially since 1985, reflecting the apparent resurgence of the Georges Bank herring population and extremely high biomass levels of mackerel. Current estimates of the mackerel stock alone exceed 2 million tons (Northeast Fisheries Center, MS 1991).

Brown et al. (1976) modeled surplus production of aggregate fish biomass off the northeastern USA and noted that the maximum sustainable yield (MSY) of the aggregate was less than the sum of the MSYs for the component species. Any attempt to update this estimate of aggregate MSY is complicated by (1) the non-equilibrium behaviour associated with the rapid decline in the herring population (which accounted for nearly one half of the total yield in the early-1970s), (2) differences in the production to biomass ratios of the species currently dominating the system relative to historical patterns, and (3) changes in effort and catch composition induced by the imposition of extended jurisdiction in 1977. Accordingly, we have not attempted to update the production model of Brown et al. (1976).

The perturbation induced by dramatic increases in fishing effort on Georges Bank by the distant water fleets resulted in important changes in system structure and productivity. The production of commercially desirable species has remained at depressed levels despite overall reductions in fishing effort relative to the period of distant water fleet activity. In part, this reflects a sharper focusing of effort on the principal groundfish by the domestic fleet. However, the increasing biomass of piscivores of little commercial value, particularly dogfish, mackerel and large skates, may further depress production levels by increasing predation mortality on both the pre-recruits and recruited components of the principal groundfish populations. The synergistic 
effects of exploitation and predation can affect the stability and resilience of these populations and result not only in lower levels of production but increased probability of a population collapse. It is possible that the observed changes in system structure may not be reversible without manipulation of predator biomass to reduce the dominance of piscivores in the system. Reduction in fishing mortality rates alone on the commercially desirable species may not be sufficient to increase recruitment and overall production. These issues can only be fully addressed in the context of an Adaptive Management Experiment (Walters, 1977) in which deliberate changes in system structure are induced and the response of the system carefully monitored.

\section{Acknowledgements}

We express our appreciation to D. Kimura and A. Rosenberg for their comments and suggestions on methodology, and to S. Clark for offering his perspective on historical developments in the Georges Bank Fisheries.

\section{References}

ALMEIDA, F. P., M. J. FOGARTY, S. H. CLARK, and J. S. IDOINE. MS 1986. An evaluation of precision of abundance estimates derived from bottom trawl surveys off the Northeastern United States. ICES C.M. Doc., No. G:91, 19 p.

ANTHONY, V. C. 1988. The New England fisheries in the 21st century. In: Proceedings: National Resources for the 21st Century. American Forestry Association, Washington, D. C.

ANTHONY, V. C., and G. T. WARING. 1980. The assessment and management of the Georges Bank herring population. ICES Rapp. Proc.-Verb., 177: 72-111.

BEDDINGTON, J. R. 1984. The response of multispecies systems to perturbations. In: Exploitation of Marine Communities, R. M. May (ed.), p. 209-225. SpringerVerlag.

BLISS, C. I. 1967. Statistics in Biology; Statistical Methods for Research in the Natural Sciences, Vol. 1. McGraw-Hill, New York, 558 p.

BROWN, B. E., J. A. BRENNAN, E. G. HEYERDAHL, M. D. GROSSLEIN, and R. C. HENNEMUTH. 1976. The effect of fishing on the marine finfish biomass of the Northwest Atlantic from the Gulf of Maine to Cape Hatteras. ICNAF Res. Bull, 12: 49-68.

BROWN, B. E., and R. G. HALLIDAY. 1983. Fisheries resources of the Northwest Atlantic-Some responses to extreme fishing perturbations. p. 96-109. In: Proceedings of the Joint Oceanographic Assembly 1982General Symposia. Canadian National Committee/ Scientific Committee on Oceanic Research, Ottawa, Ontario.

CHRISTIE, W. J., and G. R. SPANGLER (eds.). 1987. International symposium on stock assessments and yield prediction. Can. J. Fish. Aquatic. Sci., 44: Suppl. 2, $499 \mathrm{p}$.

CLARK, S. H. 1979. Application of bottom trawl survey data to fish stock assessment. Fisheries, 4: 9-15.

CLARK, S. H., and B. E. BROWN. 1977. Changes in biomass of finfish and squids from the Gulf of Maine to Cape Hatteras, 1963-1974, as determined from research vessel survey data. Fish. Bull. U.S., 75(1): $1-21$.

1979. Trends in biomass of finfishes and squids in ICNAF Subarea 5 and Statistical Area 6, 19641977, as determined from research vessel survey data. Investigación Pesquera, 43(1): 107-122.

CLARK, S. H., W. J. OVERHOLTZ, and R. C. HENNEMUTH. 1982. Review and assessment of the Georges Bank and Gulf of Maine haddock fishery. J. Northw. Atl. Fish. Sci., 3: 1-27.

CLARK, S. H., M. M. McBRIDE, and B. WELLS. MS 1984. Yellowtail flounder assessment update-1984. NMFS, NEFC Woods Hole Lab. Ref. Doc., No. 84-39, 30 p.

COHEN, E. B., and M. D. GROSSLEIN. 1987. Production on Georges Bank, p. 383-391. In: Georges Bank, R. $\mathrm{H}$. Backus (ed.). The MIT Press, Cambridge, Massachusetts, $593 \mathrm{p}$.

FOGARTY, M. J., M. P. SISSENWINE, and M. D. GROSSLEIN. 1987. Fish Population Dynamics, p. 494-507. In: Georges Bank, R. H. Backus (ed.). The MIT Press, Cambridge, Massachusetts, $593 \mathrm{p}$.

GAVARIS, S. 1980. Use of a multiplicative model to estimate catch rate and effort from commercial data. Can. J. Fish. Aquat. Sci., 37: 2272-2275.

GERMAN, A. W. 1987. History of the early fisheries: 17201930, p. 409-424. In: Georges Bank, R. H. Backus (ed.). The MIT Press, Cambridge, Massachusetts, $593 \mathrm{p}$.

GRAHAM, H. W., and E. D. PREMETZ. 1955. First year of mesh regulation in the Georges Bank haddock fishery. U.S. Fish. Wildl. Serv., Spec. Sci. Rep. Fish., 142: $20 \mathrm{p}$.

GRANGER, C. W., and P. NEWBOLD. 1977. Forecasting economic time series. Academic Press, New York, N. Y., 333 p.

GROSSLEIN, M. D. 1969. Groundfish survey program of BCF, Woods Hole. Comm. Fish. Rev., 31: 22-35.

GROSSLEIN, M. D., B. E. BROWN, and R. C. HENNEMUTH. 1979. Research, assessment, and management of a marine ecosystem in the Northwest Atlantic - A case study, p. 289-357. In: Environmental Biomonitoring, Assessment, Prediction, and Management - Certain Case Studies and Related Quantitative Issues. J. Cairns, Jr., G. P. Patil, and W. E. Waters (eds.). International Co-operative Publishing House, Fairland, Maryland, $560 \mathrm{p}$.

HEMPEL, G. (ed.). 1978. North Sea fish stocks-recent changes and their causes. ICES Rapp. Proc.-Verb., 172: $449 \mathrm{p}$.

HENNEMUTH, R. C. 1979. Man As Predator. p. 507-532. In: Contemporary Quantitative Ecology and Related Ecometrics, G. P. Patil and M. Rosenzweig (eds.). International Cooperative Publishing House, Fairland, Maryland, $695 \mathrm{p}$.

HENNEMUTH, R. C., and S. ROCKWELL. 1987. History of fisheries conservation and management, p. 430-446. In: Georges Bank, R. H. Backus (ed.). The MIT Press, Cambridge, Massachusetts, $593 \mathrm{p}$.

HERRINGTON, W. C. 1935. Modifications in gear to curtail the destruction of undersized fish in otter trawling. U.S. Bur. Fish., Invest. Rep., 24: 48 p.

HOLLING, C. S. 1973. Resilience and stability of ecological systems. Annu. Rev. Ecol. Syst., 4: 1-24.

ICNAF. 1962-72. Fishery Statistics for the years 19601970. ICNAF Stat. Bull., Vols. 10-20. 
KIMURA, D. K. 1981. Standardized measures of relative abundance based on modelling log (c.p.u.e.), and their application to Pacific ocean perch. ICES J. Cons., 39: 211-218.

1988. Analyzing relative abundance indices with log-linear models. North Amer. J. Fish. Mgmt., 8: 175-180.

LANGE, A. M. T., AND J. E. PALMER. 1985. USA historical catch data, 1904-82, for major Georges Bank fisheries. NOAA Tech. Mem., NMFS-F/NEC-39, $21 \mathrm{p}$.

MAYO, R. K., J. McGLADE, and S. H. CLARK. 1989. Exploitation and biological status of pollock, Pollachius virens (L.) in the Scotian Shelf, Georges Bank, and Gulf of Maine area. J. Northw. Atl. Fish. Sci., 9: 13-36.

NEW ENGLAND FISHERY MANAGEMENT COUNCIL. 1985. Fishery Management Plan for the Northeast MultiSpecies Fishery. New England Fishery Management Council, Saugus, Massachusetts.

NORTHEAST FISHERIES CENTER. MS 1987. Status of mixed species demersal finfish resources in New England and scientific basis for management. NMFS, NEFC, Woods Hole Lab. Ref. Doc., No. 87-08, 105 p.

MS 1991. Report of the Twelfth NEFC Stock Assessment Workshop, spring 1991. NMFS, NEFC,
Ref. Doc., No. 91-03, 187 p.

ROBSON, D. S. 1966. Estimation of the Relative Power of individual ships. ICNAF Res. Bull, 3: 5-14.

ROUNSEFELL, G. A. 1948. Development of fishery statistics in the North Atlantic. U.S. Fish Wildl. Serv., Spec. Sci. Rep., 47: 27 p.

SCHUCK, H. A. 1951. Studies of Georges Bank haddock, Part I: Landings by pounds, numbers, and sizes of fish. Fish. Bull., U.S., 52: 151-176.

SERCHUK, F. M., and S. E. WIGLEY. 1992. Assessment and management of the Georges Bank cod fishery: an historical review and evaluation. J. Northw. Atl. Fish. Sci., 13: 25-52.

SISSENWINE, M. P. 1987. Production of fish and squid, p. 347-350. In: Georges Bank, R. H. Backus (ed.). The MIT Press, Cambridge, Massachusetts, $539 \mathrm{p}$.

SMITH, W. G., and W. W. MORSE. MS 1990. Larval distribution patterns: evidence for the collapse/ recolonization of Atlantic herring on Georges Bank. ICES C.M. Doc., No. H:17, 16 p.

U.S. DEPARTMENT OF COMMERCE. 1988. Status of fishery resources off the northeastern United States for 1988. NOAA Tech. Mem., NMFS-F/NEC-63, $135 \mathrm{p}$.

WALTERS, C. J. 1987. Adaptive management of renewable resources. MacMillan, New York, 374 p. 
APPENDIX 1. Catch (tons, live) by country group and species group, 1960-87.

\begin{tabular}{|c|c|c|c|c|c|c|}
\hline Year & $\begin{array}{l}\text { Country } \\
\text { group }\end{array}$ & $\begin{array}{l}\text { Principal } \\
\text { groundfish }\end{array}$ & $\begin{array}{c}\text { Other } \\
\text { groundfish }\end{array}$ & Pelagics & $\begin{array}{l}\text { Other } \\
\text { fish }\end{array}$ & Total \\
\hline \multirow[t]{3}{*}{1960} & CAN & 96 & 16924 & 0 & 3029 & 20049 \\
\hline & USA & 77250 & 50347 & 0 & 0 & 127597 \\
\hline & Total & 77346 & 67271 & 0 & 3029 & 147646 \\
\hline \multirow[t]{5}{*}{1961} & BUL & 69 & 524 & 67928 & 0 & 68521 \\
\hline & CAN & 383 & 58 & 0 & 0 & 441 \\
\hline & USA & 87388 & 45046 & 2690 & 444 & 135568 \\
\hline & OTH & 0 & 0 & 140 & 0 & 140 \\
\hline & Total & 87840 & 45628 & 70758 & 444 & 204670 \\
\hline \multirow[t]{5}{*}{1962} & BUL & 8155 & 47989 & 153921 & 0 & 210065 \\
\hline & CAN & 5969 & 535 & 0 & 0 & 6504 \\
\hline & POL & 143 & 0 & 391 & 1 & 535 \\
\hline & USA & 101065 & 26214 & 2706 & 24188 & 154173 \\
\hline & Total & 115332 & 74738 & 157018 & 24189 & 371277 \\
\hline \multirow[t]{4}{*}{1963} & BUL & 8880 & 110994 & 100557 & 4121 & 224552 \\
\hline & CAN & 16659 & 1153 & 274 & 0 & 18086 \\
\hline & USA & 103655 & 64180 & 2824 & 1114 & 171773 \\
\hline & Total & 129194 & 176327 & 103655 & 5235 & 414411 \\
\hline \multirow[t]{7}{*}{1964} & BUL & 11414 & 173212 & 131654 & 19542 & 335822 \\
\hline & CAN & 19362 & 2071 & 2555 & 124 & 24112 \\
\hline & POL & 50 & 0 & 35 & 638 & 723 \\
\hline & ESP & 20 & 2 & 0 & 0 & 22 \\
\hline & USA & 113354 & 57871 & 1101 & 6053 & 178379 \\
\hline & OTH & 713 & 334 & 0 & 3 & 1050 \\
\hline & Total & 144913 & 233490 & 135345 & 26360 & 540108 \\
\hline \multirow[t]{7}{*}{1965} & BUL & 380759 & 70487 & 39556 & 9871 & 500673 \\
\hline & CAN & 26065 & 2474 & 3 & 20 & 28562 \\
\hline & GDR & 740 & 0 & 1993 & 345 & 3078 \\
\hline & $\mathrm{POL}$ & 1977 & 0 & 1448 & 1116 & 4541 \\
\hline & ESP & 69 & 0 & 0 & 0 & 69 \\
\hline & USA & 136216 & 24113 & 1813 & 17173 & 179315 \\
\hline & Total & 545826 & 97074 & 44813 & 28525 & 716238 \\
\hline \multirow[t]{8}{*}{1966} & BUL & 188414 & 101683 & 126657 & 39544 & 456298 \\
\hline & CAN & 34123 & 5230 & 1 & 97 & 39451 \\
\hline & GDR & 486 & 304 & 4855 & 3 & 5648 \\
\hline & POL & 318 & 0 & 14479 & 1304 & 16101 \\
\hline & ESP & 9486 & 45 & 0 & 0 & 9531 \\
\hline & USA & 134684 & 20124 & 1543 & 4626 & 160977 \\
\hline & OTH & 99 & 10 & 0 & 2 & 111 \\
\hline & Total & 367610 & 127396 & 147535 & 45576 & 688117 \\
\hline \multirow[t]{9}{*}{1967} & BUL & 76730 & 38866 & 138443 & 15636 & 269675 \\
\hline & CAN & 21811 & 7142 & 1306 & 61 & 30320 \\
\hline & FRG & 0 & 24 & 28261 & 3 & 28288 \\
\hline & GDR & 112 & 0 & 21719 & 24 & 21855 \\
\hline & POL & 322 & 748 & 38184 & 2008 & 41262 \\
\hline & ESP & 16085 & 165 & 0 & 0 & 16250 \\
\hline & USA & 107552 & 25211 & 1940 & 3381 & 138084 \\
\hline & OTH & 21 & 3 & 0 & 0 & 24 \\
\hline & Total & 222633 & 72159 & 229853 & 21113 & 545758 \\
\hline \multirow[t]{4}{*}{1968} & BUL & 52128 & 35234 & 164487 & 32997 & 284846 \\
\hline & CAN & 18994 & 3344 & 15135 & 85 & 37558 \\
\hline & FRG & 50 & 3 & 71097 & 0 & 71150 \\
\hline & GDR & 13 & 160 & 70373 & 27 & 70573 \\
\hline
\end{tabular}


APPENDIX 1. Continued.

\begin{tabular}{|c|c|c|c|c|c|c|}
\hline Year & $\begin{array}{l}\text { Country } \\
\text { group }\end{array}$ & $\begin{array}{l}\text { Principal } \\
\text { groundfish }\end{array}$ & $\begin{array}{c}\text { Other } \\
\text { groundfish }\end{array}$ & Pelagics & $\begin{array}{l}\text { Other } \\
\text { fish }\end{array}$ & Total \\
\hline \multirow[t]{5}{*}{1968} & POL & 4781 & 0 & 73658 & 1584 & 80023 \\
\hline & ESP & 17636 & 380 & 0 & 0 & 18016 \\
\hline & USA & 96146 & 25725 & 1793 & 3243 & 126907 \\
\hline & OTH & 39 & 0 & 425 & 10 & 474 \\
\hline & Total & 189787 & 64846 & 396968 & 37946 & 689547 \\
\hline \multirow[t]{9}{*}{1969} & BUL & 95066 & 76360 & 157977 & 51333 & 380736 \\
\hline & CAN & 10713 & 3404 & 947 & 7 & 15071 \\
\hline & $F R G$ & 17 & 6 & 62086 & 0 & 62109 \\
\hline & GDR & 91 & 176 & 45926 & 8309 & 54502 \\
\hline & POL & 1605 & 0 & 45789 & 9013 & 56407 \\
\hline & ESP & 14798 & 226 & 0 & 0 & 15024 \\
\hline & USA & 86253 & 18078 & 3832 & 3659 & 111822 \\
\hline & OTH & 0 & 0 & 12786 & 0 & 12786 \\
\hline & Total & 208543 & 98250 & 329343 & 72321 & 708457 \\
\hline \multirow[t]{9}{*}{1970} & BUL & 34981 & 10261 & 98523 & 25156 & 168921 \\
\hline & CAN & 5015 & 1835 & 8 & 2 & 6860 \\
\hline & $\mathrm{FRG}$ & 3 & 941 & 82718 & 0 & 83662 \\
\hline & GDR & 800 & 1239 & 29660 & 2060 & 33759 \\
\hline & JPN & 241 & 366 & 3487 & 6596 & 10690 \\
\hline & POL & 709 & 0 & 95819 & 5168 & 101696 \\
\hline & ESP & 7656 & 67 & 0 & 0 & 7723 \\
\hline & USA & 77849 & 16463 & 6783 & 2580 & 103675 \\
\hline & Total & 127254 & 31172 & 316998 & 41562 & 516986 \\
\hline \multirow[t]{9}{*}{1971} & BUL & 96211 & 36438 & 133903 & 42882 & 309434 \\
\hline & CAN & 4936 & 2833 & 12863 & 1 & 20633 \\
\hline & FRG & 3 & 148 & 55568 & 5 & 55724 \\
\hline & GDR & 97 & 1202 & 22187 & 3304 & 26790 \\
\hline & JPN & 146 & 1259 & 3705 & 9771 & 14881 \\
\hline & POL & 378 & 130 & 112791 & 10390 & 123689 \\
\hline & ESP & 8770 & 189 & 3 & 3281 & 12243 \\
\hline & USA & 66019 & 11326 & 6719 & 1835 & 85899 \\
\hline & Total & 176560 & 53525 & 347739 & 71469 & 649293 \\
\hline \multirow[t]{9}{*}{1972} & BUL & 116584 & 68929 & 161524 & 79447 & 426484 \\
\hline & CAN & 3317 & 2090 & 54 & 8 & 5469 \\
\hline & FRG & 233 & 73 & 28817 & 166 & 29289 \\
\hline & GDR & 307 & 2143 & 62555 & 1457 & 66462 \\
\hline & JPN & 232 & 770 & 2999 & 8538 & 12539 \\
\hline & POL & 176 & 424 & 102493 & 10518 & 113611 \\
\hline & ESP & 7799 & 108 & 6 & 5315 & 13228 \\
\hline & USA & 58697 & 8035 & 6260 & 1484 & 74476 \\
\hline & Total & 187345 & 82572 & 364708 & 106933 & 741558 \\
\hline \multirow[t]{9}{*}{1973} & BUL & 114604 & 64002 & 204883 & 35672 & 419161 \\
\hline & CAN & 4879 & 2228 & 5150 & 0 & 12257 \\
\hline & FRG & 1 & 288 & 35879 & 867 & 37035 \\
\hline & GDR & 239 & 443 & 107413 & 12799 & 120894 \\
\hline & JPN & 253 & 70 & 4093 & 6302 & 10718 \\
\hline & POL & 751 & 1808 & 150556 & 16875 & 169990 \\
\hline & ESP & 6366 & 863 & 0 & 10147 & 17376 \\
\hline & USA & 64835 & 11723 & 13451 & 2382 & 92391 \\
\hline & Total & 191928 & 81425 & 521425 & 85044 & 879822 \\
\hline \multirow[t]{5}{*}{1974} & BUL & 110315 & 21663 & 138679 & 39354 & 310011 \\
\hline & CAN & 1912 & 3632 & 217 & 4 & 5765 \\
\hline & FRG & 105 & 40 & 27676 & 13 & 27834 \\
\hline & GDR & 112 & 0 & 41274 & 1136 & 42522 \\
\hline & JPN & - & 264 & 6253 & 7264 & 13879 \\
\hline
\end{tabular}


APPENDIX 1. Continued.

\begin{tabular}{|c|c|c|c|c|c|c|}
\hline Year & $\begin{array}{c}\text { Country } \\
\text { group }\end{array}$ & $\begin{array}{l}\text { Principal } \\
\text { groundfish }\end{array}$ & $\begin{array}{l}\text { Other } \\
\text { groundfish }\end{array}$ & Pelagics & $\begin{array}{l}\text { Other } \\
\text { fish }\end{array}$ & Total \\
\hline \multirow[t]{5}{*}{1974} & POL & 598 & 140 & 78637 & 9966 & 89341 \\
\hline & ESP & 7171 & 725 & 0 & 7580 & 15476 \\
\hline & USA & 60426 & 12764 & 19316 & 9426 & 101932 \\
\hline & OTH & 603 & 53 & 0 & 0 & 656 \\
\hline & Total & 181340 & 39281 & 312052 & 74743 & 607416 \\
\hline \multirow[t]{10}{*}{1975} & BUL & 74407 & 19392 & 155731 & 39425 & 288955 \\
\hline & CAN & 3339 & 4955 & 4 & 0 & 8298 \\
\hline & FRG & 53 & 155 & 27715 & 48 & 27971 \\
\hline & GDR & 60 & 96 & 55791 & 2182 & 58129 \\
\hline & JPN & 20 & 412 & 2904 & 3719 & 7055 \\
\hline & POL & 401 & 418 & 65744 & 3795 & 70358 \\
\hline & ESP & 4126 & 240 & 22 & 2881 & 7269 \\
\hline & USA & 59901 & 7421 & 12372 & 1963 & 81657 \\
\hline & $\mathrm{OTH}$ & 60 & 0 & 220 & 635 & 915 \\
\hline & Total & 142367 & 33089 & 320503 & 54648 & 550607 \\
\hline \multirow[t]{10}{*}{1976} & BUL & 52913 & 18818 & 79818 & 21525 & 173074 \\
\hline & CAN & 3960 & 2612 & 0 & 104 & 6676 \\
\hline & FRG & 92 & 1007 & 13222 & 1123 & 15444 \\
\hline & GDR & 0 & 24 & 10644 & 1119 & 11787 \\
\hline & JPN & 10 & 19 & 7669 & 2680 & 10378 \\
\hline & POL & 303 & 1039 & 42119 & 7060 & 50521 \\
\hline & ESP & 1700 & 12 & 114 & 3991 & 5817 \\
\hline & USA & 53595 & 9523 & 20733 & 2966 & 86817 \\
\hline & OTH & 23 & 10 & 276 & 514 & 823 \\
\hline & Total & 112596 & 33064 & 174595 & 41082 & 361337 \\
\hline \multirow[t]{9}{*}{1977} & BUL & 48263 & 5970 & 5193 & 6324 & 65750 \\
\hline & CAN & 9431 & 3889 & 417 & 30 & 13767 \\
\hline & GDR & 0 & 0 & 782 & 0 & 782 \\
\hline & JPN & 5 & 26 & 650 & 2222 & 2903 \\
\hline & POL & 0 & 39 & 51 & 180 & 270 \\
\hline & ESP & 13 & 6 & 38 & 915 & 972 \\
\hline & USA & 64735 & 11657 & 7417 & 2416 & 86225 \\
\hline & OTH & 11 & 12 & 334 & 31 & 388 \\
\hline & Total & 122458 & 21599 & 14882 & 12118 & 171057 \\
\hline \multirow[t]{6}{*}{1978} & BUL & 10614 & 1695 & 322 & 1995 & 14626 \\
\hline & CAN & 19468 & 5324 & 0 & 6 & 24798 \\
\hline & JPN & 79 & 7 & 443 & 2216 & 2745 \\
\hline & ESP & 10 & 9 & 30 & 979 & 1028 \\
\hline & USA & 74606 & 14976 & 21909 & 2535 & 114026 \\
\hline & Total & 104777 & 22011 & 22704 & 7731 & 157223 \\
\hline \multirow[t]{7}{*}{1979} & BUL & 1409 & 172 & 17 & 123 & 1721 \\
\hline & CAN & 11318 & 3244 & 0 & 14 & 14576 \\
\hline & JPN & 244 & 90 & 116 & 1338 & 1788 \\
\hline & POL & 0 & 0 & 0 & 167 & 167 \\
\hline & ESP & 94 & 53 & 19 & 988 & 1154 \\
\hline & USA & 83739 & 19491 & 17384 & 5693 & 126307 \\
\hline & Total & 96804 & 23050 & 17536 & 8323 & 145713 \\
\hline \multirow[t]{8}{*}{1980} & BUL & 3 & 1 & 1 & 41 & 46 \\
\hline & CAN & 18594 & 6321 & 1 & 40 & 24956 \\
\hline & JPN & 426 & 36 & 301 & 3889 & 4652 \\
\hline & POL & 0 & 0 & 5 & 124 & 129 \\
\hline & ESP & 259 & 86 & 22 & 3491 & 3858 \\
\hline & USA & 95695 & 16947 & 25970 & 3906 & 142518 \\
\hline & $\mathrm{OTH}$ & 0 & 0 & 0 & 2 & 2 \\
\hline & Total & 114977 & 23391 & 26300 & 11493 & 176161 \\
\hline
\end{tabular}


APPENDIX 1. Continued.

\begin{tabular}{|c|c|c|c|c|c|c|}
\hline Year & $\begin{array}{l}\text { Country } \\
\text { group }\end{array}$ & $\begin{array}{l}\text { Principal } \\
\text { groundfish }\end{array}$ & $\begin{array}{c}\text { Other } \\
\text { groundfish }\end{array}$ & Pelagics & $\begin{array}{l}\text { Other } \\
\text { fish }\end{array}$ & Total \\
\hline \multirow[t]{6}{*}{1981} & CAN & 14380 & 6010 & 0 & 0 & 20390 \\
\hline & JPN & 378 & 43 & 439 & 2175 & 3035 \\
\hline & POL & 2 & 1 & 0 & 11 & 14 \\
\hline & ESP & 498 & 307 & 223 & 9625 & 10653 \\
\hline & USA & 92163 & 15138 & 33020 & 13407 & 153728 \\
\hline & Total & 107421 & 21499 & 33682 & 25218 & 187820 \\
\hline \multirow[t]{6}{*}{1982} & CAN & 23024 & 6486 & 0 & 0 & 29510 \\
\hline & JPN & 93 & 81 & 246 & 1433 & 1853 \\
\hline & ESP & 238 & 173 & 21 & 2668 & 3100 \\
\hline & USA & 104879 & 13899 & 13323 & 18043 & 150144 \\
\hline & OTH & 0 & 0 & 0 & 22 & 22 \\
\hline & Total & 128234 & 20639 & 13590 & 22166 & 184629 \\
\hline \multirow[t]{7}{*}{1983} & CAN & 15795 & 4475 & 0 & 0 & 20270 \\
\hline & JPN & 69 & 50 & 122 & 1094 & 1335 \\
\hline & POL & 0 & 0 & 141 & 2 & 143 \\
\hline & ESP & 67 & 48 & 21 & 972 & 1108 \\
\hline & USA & 103952 & 12911 & 4293 & 12570 & 133726 \\
\hline & OTH & 0 & 0 & 0 & 10 & 10 \\
\hline & Total & 119883 & 17484 & 4577 & 14648 & 156592 \\
\hline \multirow[t]{6}{*}{1984} & CAN & 7341 & 2304 & 1 & 6 & 9652 \\
\hline & JPN & 19 & 22 & 36 & 641 & 718 \\
\hline & POL & 1 & 2 & 134 & 5 & 142 \\
\hline & ESP & 131 & 29 & 13 & 1539 & 1712 \\
\hline & USA & 84614 & 14203 & 12396 & 11454 & 122667 \\
\hline & Total & 92106 & 16560 & 12580 & 13645 & 134891 \\
\hline \multirow[t]{7}{*}{1985} & CAN & 14263 & 1813 & 1 & 5 & 16082 \\
\hline & JPN & 15 & 6 & 15 & 67 & 103 \\
\hline & POL & 15 & 0 & 1277 & 48 & 1340 \\
\hline & ESP & 159 & 168 & 0 & 1328 & 1655 \\
\hline & USA & 63454 & 12543 & 8406 & 9119 & 93522 \\
\hline & OTH & 0 & 0 & 0 & 70 & 70 \\
\hline & Total & 77906 & 14530 & 9699 & 10637 & 112772 \\
\hline \multirow[t]{7}{*}{1986} & CAN & 12300 & 2423 & 11 & 3 & 14737 \\
\hline & GDR & 13 & 6 & 4020 & 80 & 4119 \\
\hline & JPN & 6 & 1 & 8 & 64 & 79 \\
\hline & POL & 12 & 1 & 1756 & 7 & 1776 \\
\hline & ESP & 162 & 2 & 9 & 1493 & 1666 \\
\hline & USA & 45366 & 10604 & 8665 & 11798 & 76433 \\
\hline & Total & 57859 & 13037 & 14469 & 13445 & 98810 \\
\hline \multirow[t]{5}{*}{1987} & CAN & 16630 & 3003 & 17 & 1 & 19651 \\
\hline & GDR & 2 & 0 & 2548 & 29 & 2579 \\
\hline & POL & 0 & 0 & 986 & 4 & 990 \\
\hline & USA & 47861 & 14989 & 11649 & 10745 & 85244 \\
\hline & Total & 64493 & 17992 & 15200 & 10779 & 108464 \\
\hline
\end{tabular}

